\title{
Contribution of an integrated laboratory on product design to local development: a case study at Montes Claros, Minas Gerais
}

\author{
Eduardo Romeiro Filho ${ }^{a}$, Marcus Gonçalves Caldeira ${ }^{b}$, Frederico Mineiro Lopes ${ }^{b}$, Alexander Thorsten Nitsche ${ }^{b}$ \\ aFederal University of Minas Gerais \\ bEducational Foundation of Montes Claros
}

e-mails: romeiro@ufmg.br; marcuscaldeira@femc.edu.br; fredmineirolopes@bol.com.br; atnitsche@rogers.com

\begin{abstract}
Product design and engineering developed by companies, especially SMEs (small and medium enterprises), is a key competitive factor. The Brazilian industrial sector lacks a systematic approach that integrates different variables required by the market in order to help determine product excellence. It is a way to reduce the economic differences between the regions in the country. This paper brings a contribution to this goal, presenting the development process and first results of an Integrated Laboratory for Product Design (LIDEP). The 'LIDEP' works under a multidisciplinary and systemic approach, developing new products from existing demand and transferring technologies on design methodology, prototyping and design management to SMEs and educational institutions. The 'LIDEP' initiative is developed in Montes Claros, an important city in the northern region of the State of Minas Gerais, providing competitive conditions to local SMEs, adding significant value to products by making use of systemic design, market analysis and leveraging technical regulations.
\end{abstract}

Keywords: product design, product development process, local development.

\section{Introduction}

The northern region of Minas Gerais is traditionally recognized as one of the economically less developed areas in Brazil. It is inside the so-called "polygon of drought" with an economic structure largely based around the agribusiness. Montes Claros city is considered the "capital" of Northern of Minas Gerais, having the most developed industrial cluster in the region, although its industrial potential remained largely unexplored (MAIA, 2001, p. 52-58). The city is part of the state biotechnology cluster having companies such as Vallée (a pharmaceutical business, dedicated to the production of Veterinary Medicine), and Novo Nordisk (healthcare company), it also is home to large industrial companies such as: Nestlé, Mitsubishi Group, Coteminas, Lafarge Cement,among others. However, despite the presence of large companies, the city's industrial park lacks the presence of small industrial enterprises, extremely important in the regional economic performance rates.

Since the 1990s this region of Montes Claros has gradually improved its industrial growth, mainly through new investments by large companies. Adding to this, there is also an increasing number of young professionals, originating from new technical and graduation courses offered by the city's education institutions (There are, by 2010, six new graduate institutes). It is natural to expect an increase in the number of new ventures in the region in the coming years. For these ventures to properly succeed and prosper, an adequate policy of industrial and technological development is necessary. One of the opportunities to be explored is the ability to develop new products from the region's existing product offerings. The development of these new offerings will promote the research, creation, development and commercialization of products and services to meet the local needs and explore the local potential. This development is extremely important as several studies demonstrate how the main factors influencing sustained economic growth are based on new knowledge obtained from scientific discoveries and technological and managerial innovations. Mynott (2002) notes that only by developing new technologies and innovations a country can maintain a sustainable growth in wealth and business competitiveness.

In a region where industrial companies are extremely important for economic growth, studying a structured approach focused on creating new ventures can play an important role in achieving sustainable development and decreasing failed attempts to start a business. Proposals such as this project can help change a trend of low profitability or even business failure, a common trend in Brazil, where $59 \%$ of businesses close their activities in the first year of operation (SEBRAE, 2004). 
This paper makes a contribution to the study of this subject, presenting a research group, part of the Integrated Laboratory for Product Design (LIDEP), in Montes Claros. This project is a partnership between UFMG - Universidade Federal de Minas Gerais, located in Belo Horizonte and FACIT - Faculty of Science and Technology of Montes Claros, linked to FEMC - Fundação Educacional Montes Claros which has the following objectives: (1) knowledge transfer in product development between institutions, (2) the creation of a research group on product design in Montes Claros, integrated with others in Belo Horizonte, (3) development of conditions for joint research, (4) contribute to the creation of new businesses in Montes Claros (through joint actions within one of the local business incubators) and (5) contribute to the industrial development in the northern region of Minas Gerais.

\section{Action strategy}

The project involved three main stages. The first was a survey study of local demands. This study aimed to investigate the potential market in the region of Montes Claros, based on items used by companies in their industrial processes. This was accomplished through two studies, involving researchers from both institutions under the supervision of the LIDEP Montes Claros' project coordinator.

- The first study was conducted with companies in the industrial park in Montes Claros. The data collected in this research assessed the main items used by companies in their industrial processes, such as equipment, equipment maintenance items, raw materials, services, and others. The survey also identified the main suppliers used by those companies, the minimum quality requirements and the minimum and maximum price for each item researched.

- As soon as this survey was completed a second study aimed at educational institutions started aimed at assessing the local potential to generate expertise in industrial design and production. This research took into account existing courses in technical and academic institutions and their capacity to develop graduates with a focus on Research and Development.

After collecting this information the project team began the second stage coordinated by the LIDEP Belo Horizonte, and including all the members of both research teams. At this stage the team analyzed the data collected in the initial step in order to develop an initial proposal for a series of products based on existing local technical competences and aimed at fulfilling local industrial demand. From this initial listing of proposed products, a study was conducted using a New Product Development and Services - DNPS strategy (NITSCHE, 2004), to identify which products and services were actually viable to be developed. This method takes into account factors such as: initial investments, production and assembly costs, raw materials needs, equipment maintenance, local labor expertise, consumer market (including other regions), among others that are key in defining the investment required for a new venture. By using the DNPS method the project team also extends the product outlook beyond the regional product demand analysis by studying the technical and economic feasibility of the main product lines across broader market geographies.

Once the products with the best technical and economic feasibility to be manufactured and marketed were defined, the project team selected two companies to study in the final stage of the research. At this stage, based on the competencies of the project team involved, a few product and services were selected to be developed, based on the DNPS methodology. It may not be possible for the project team to work through all the stages of the methodology with the selected companies. However, the project team and selected companies will work together to complete the initial stages considered the most important and critical by several authors such as Ottosson (2004), Nobelius and Trygg (2002), Thomke and Fujimoto (2000) and Cooper (2001).

\section{Research and design methodologies}

The main methodologies used during the different project phases were Case Study (YIN, 2008) and Survey (FIGUEIREDO, 2006), and Product Design and Development Methodologies (ROOZEMBURG; EEKELS, 1995; ROMEIRO FILHO et al., 2009) especially those developed from some of our previous work (BANDEIRA, 2003; ROMEIRO FILHO; CRUZ, 2003; ROMEIRO FILHO, 2003; VIEIRA, 2002). This project takes into account the qualitative data collection in an attempt to examine and understand a complex and particular social phenomenon. This is made possible by using the case study methodology, which in addition to

[...] allowing an investigation of real-life events it also contributes to the preservation of the most significant holistic characteristics of the research (YIN, 2008, p.4).

The case study has a qualitative approach and is focused on the assessment of social problems. It combines a number of sources of evidence such as interviews, direct observation, participant observation, documentation, files and physical artifacts. It should be noted that among these sources of evidence no one is better than another, they are in fact complementary. Based on this, it is relevant to mention that this study will support as many sources of research as necessary in order to have a better understanding of the aspects related to the object of this study. 
The research method plays an important role in the study, as it establishes a link between the researcher and reality in order for the researcher to be able to base his work on theory and from it observe or apply the knowledge gained in order to support the practical phenomena, as practice is the way for mediation and dialogue between researchers and research subjects. This is important given that some of the local firms surveyed did not have a proper production control strategy and lack a proper control about the company's production results. Based on this, the selected research method improves the knowledge the companies surveyed now have of their own operations. Given those arguments and the complex nature of qualitative data collection, it is observed that the decision to use a Case Study methodology was important. Its use is clearly justified as it shows that there is proper alignment of the object of study with the interests of this research. Additionally, if there is a need to obtain a broader understanding of the local companies' operations, new research can be performed at a larger number of companies using the case study results to guide additional research.

A survey should be performed, to collect information in a quantitative manner using tools such as questionnaires and interviews (FIGUEIREDO, 2006). It is important to identify the nature of the survey research; it can be exploratory, descriptive or explanatory. To Pinsonneault and Kraemer (1993), a descriptive survey aims to inform the investigator about situations, facts, opinions or behaviors that occur in the researched population. The descriptive analysis of the research seeks to create a map of the distribution of a phenomenon in the population studied, taken as a whole or divided into sub-groups. The purpose of this survey is to describe the distribution or make comparisons between distributions. Thus, considering its objectives, this research project is characterized as a descriptive survey. Pinsonneault and Kraemer (1993) assign three basic characteristics for a research survey. First, it aims to provide quantitative descriptions of certain aspects of the studied population. The analysis may consist of establishing relationships between variables or making projections about the population. Second, data collection is performed, usually from structured and pre-defined questionnaires. The answers to the questionnaire constitute the data to be analyzed. Finally, information is generally collected within a fraction, or specific sample, of the target population. This is why this sample should be representative and relevant, as otherwise there is no guarantee that the analysis will be relevant in statistical terms. It is also important as a certain degree of generalization is usually needed with respect to the research conclusion.

In summary, it is believed that the use of different methodological tools throughout the project, whether in research for making the diagnosis, whether in product development and, ultimately, the characterization of one or more design methods appropriate for the local development, is relevant to the proposed objectives. Based on this the LIDEP is applying the research methods based on the needs observed throughout the work, including as one of the objectives the development of scientific research skills among the project participants in Montes Claros, being that they are undergraduate students from the local LIDEP or staff members from the regional companies studied.

\section{The project development}

From the initial situation observed in Montes Claros, the implementation of an integrated laboratory working as a local branch of LIDEP was proposed. The LIDEPMontes Claros began its work having as main objective the analysis of industrial development possibilities based on local supply chains and the academic and technical potential of local professionals. This approach used New Product development methodologies, in order to apply for government grants directed to regional industrial development. The project called LIDEP-Moc, underway since 2005, includes research teams from UFMG and FACIT. The initiative aims to integrate researchers and transfer the results to local companies, especially small and medium ones. To achieve these goals, the following steps have been proposed:

- Make a broad literature review on the research subject, in order to create a "state of the art" database about the subject matter (design and research methodologies). This review was undertaken by the team based in Belo Horizonte.

- Prioritize the study on local companies that could be used as basis for "multiple case studies". This selection would be based on the representativeness of these companies to the regional economy, the alignment of their product to the scope of the research, and the ability to interact with the researchers involved. Initially around seventy companies in Montes Claros were selected to be surveyed, after the discussed filters were applied the research was than conducted on twenty of these companies.

- Analysis of the product development stages used in these companies, in order to identify bottlenecks that could compromise the product innovation process. This step was difficult to achieve because in general the companies surveyed had no formal processes (or even informal) of product development. There were many visits to companies considered cutting edge in Montes Claros and it was found that the processes they used were "imported" from their headquarters and / or other companies or from other more developed industrial centers such as the ones 
in Sao Paulo and Belo Horizonte (this includes hiring professionals from these centers). It was decided then to use a related database from previous research (FERNANDES, 2005; OLIVEIRA, 2000), conducted in Belo Horizonte. In addition, a survey about product development process and the use of new technologies (such as Computer Aided Design) in the region was performed. The results demonstrate that those companies were in a similar level when compared to companies in more developed areas (i.e. the metropolitan region of Belo Horizonte). As part of this approach, some opportunities were identified for case studies to be conducted at local companies complementing this objective.

- Identify the critical items related to the company's productive process in order to characterize the aspects that directly influence the project's team decision when developing a new product. As a note it was not possible to perform this step, taking into consideration the reasons stated in the previous item. However, preliminary observations indicate that the existing issues at the Montes Claros companies (at least for larger companies) show a similarity to those observed in other regions in the country, even the ones with higher rates of economic development. This similarity was observed in other of our previous work (such ROMEIRO FILHO, 1993; 1997).

- Development of methods and processes to support product development from the specific conditions observed in the surveyed companies, aiming to reduce the existing bottlenecks. From the discussion above a set of tools have been developed taken as a start point previous work undertaken by the research group. Those tools are to be tested and implemented in a future next step. Those tools were developed from studies conducted by the research group in several companies, mostly in the state of Minas Gerais.

- Based on the data collected promote the development of pilot projects to have the researched products manufactured in the region. This stage is dependent of financial support and interest from local companies. Two pilot projects were negotiated with local partners (small companies in the area). The presence of the LIDEP-Moc in the Business Incubator of the FACIT contributed to this partnership with the incubated companies helping improving their incubation process.

- Consolidate an appropriate product design methodology based on the local conditions observed in SMEs which is to be consistent with the economic and technical regional reality. It is expected that this methodology is to be developed based on studies conducted in Belo Horizonte and Montes Claros by the research teams.

- Development of a suitable method for product development and the proper conditions to have it transferred to interested companies and/or to encourage the creation of new companies that use this method as their base for new product development. In order to merge the research results from the different LIDEPs a seminar was held in July 2007 in Montes Claros, when the group presented the overall results of the existing projects and, in particular, the new product development method developed and the research and methodological tools used for its design. From this, the research center in Montes Claros can, from a close collaboration with the researchers from Belo Horizonte, act as an intermediate of knowledge transfer to interested companies, especially those ones incubated at the FACIT Incubator.

- Create an appropriate scenario of capabilities for the creation, in Montes Claros, of a study core focused on innovation and product development. This center, located in the business incubator of the FACIT, is coordinated by professor of Montes Claros, in conjunction with the group from Belo Horizonte aiming to develop new researches in the field, to form a "network of studies on product development." This center will act as an extension of the Integrated Laboratory in Montes Claros, in order to create a a common field of work to developed news researches, involving researchers from several institutions.

\section{Results}

In 2008 the LIDEP developed a consulting project for Clair Mont, a local glass frame producer whose industrial plant is installed in Montes Claros. This project was conducted by engineering students from FACIT and the results were presented in a seminar held in December 2008.

In 2009 the LIDEP-Moc developed a consulting project where the main goal was to identify opportunities for improvements in the manufacturing process of local companies, including: Alpha - Precision Assemblies, ArtPel - Packaging, Vida - Dairy Products and Raem - moulded Products. The results were presented at the Science, Technology and Culture Workshop held at the FACIT.

In 2010, the LIDEP-Moc installed in the FACIT a Junior Company specialized in engineering, project management and technology consulting that will have as it main focus local business. This initiative aims to involve the academic community in research activities and to promote entrepreneurship through the creation of new businesses, contributing to regional economic development. Furthermore a series of other research activities were developed involving the academic community in the FACIT, with the objective 
of identifying market trends and opportunities for creating new businesses in the areas of Production Engineering, Computer Engineering, Chemical Engineering, Control and Automation and Telecommunication Engineering.

From these activities the LIDEP seeks, by developing research projects, to encourage students to embrace the scientific research and to learn how to identify and use the entrepreneurial potential of the FACIT to foster the generation of new venture that will contribute to the socioeconomic development of the region. The partner companies and participants of the projects developed by the LIDEP-Moc were unable to measure the quantitative gains achieved with the research practices during the time this project was conducted although following qualitative gains were highlighted:

- Access to scientific knowledge through direct contact with students and teachers;

- Improvement in innovation and technology;

- Encouragement of research and scientific initiation;

- Social responsibility;

- Bring companies close to the academic environment;

- Creation of a professional network;

- Identification of professional talent for future hiring;

- Promotion and strengthening the local brands in the community;

- Contribution to regional development;

- Promotion of entrepreneurship and generation of new business in the region.

- Creating options to the development of new projects.

\section{Conclusion}

Among the actions of the government and private research agencies in Brazil is the incentive to further actions in areas where the scientific tradition is still undeveloped. In addition there is an effort to create conditions to promote the economic development in order to improve the social indicators in Brazil which deeply rely in reducing the regional differences. In this sense the joint actions between different educational institutions, whether public or private, play an important role in this process. Moreover, in Brazil, the public universities have an important task to support scientific and technological development in the regions under their influence. Within this scenario this project seeks to contribute to improve the current situation, working on issues considered important for economic growth and social improvement.

Since 2007 the LIDEP-Moc has been developing its own researches acting independently from the LIDEP Belo Horizonte coordination characterizing itself as a self sufficient research branch. This fact represents an enormous gain as the northern region of Minas Gerais had little research The LIDEP coordinator expect the two labs to create a partnership relationship in lieu of an unit under the coordination of the Belo Horizonte lab which will lead to joint projects using the full potential of the two research institutions.

It is hoped that the experience gained out in Montes Claros, in spite of its limitations (such as the difficulty to obtain and evaluate quantitative data from local firms) will provide subsidies to regional development and provide a basis for other experiments in other country areas with a similar socio-economic development.

\section{Acknowledgements}

The authors of this paper would like to thanks the CNPq - National Council for Scientific and Technological Development which sponsors this research project and a postdoctoral fellowship to one of the authors. They also would like to thanks CAPES and FAPEMIG by the financial support to this research.

\section{References}

BANDEIRA, A. P. V. Aplicação do Ecodesign em Empresa Mineira e a Percepção dos Funcionários: um estudo de Caso. 2003. Dissertação (Mestrado em Engenharia de Produção)-Universidade Federal de Minas Gerais, Belo Horizonte, 2003.

COOPER, R. G. Winning at New Products: Accelerating the Process from Idea to Launch. 3th ed. Cambridge: Perseus Publishing, 2001.

FERnANDES, J. M. A Formalização de Procedimentos e seu Papel na Integração da Atividade Projetual. 2005. Dissertação (Mestrado em Engenharia de Produção)Universidade Federal de Minas Gerais, Belo Horizonte, 2005.

FIGUEIREDO, A. C. Utilização do CAD na Indústria Mineira: Um Survey no Setor Metal-mecânico. 2003. Dissertação (Mestrado em Engenharia de Produção)Universidade Federal de Minas Gerais, Belo Horizonte, 2003.

MAIA, M. F. R. A importância da Indústria Têxtil no Desenvolvimento do Município de Montes Claros. 2001. 119 f. Dissertação (Mestrado em Ciências Econômicas)Faculdade de Ciência Econômicas, Universidade Federal de Minas Gerais, Belo Horizonte, 2001.

MYNOTT, C. B. A Strategic Overview of UK Product Development. Journal of Industrial Design, v. 12, n. 1, p. 25-36, 2002.

NITSCHE, A. T. The Product Development Process as a Tranfer Technology Tool. 2004. Dissertação (Mestrado em Engenharia de Produção)-Universidade Federal de Minas Gerais, Belo Horizonte, 2004.

NOBELIUS, D.; TRYGG, L. Stop Chasing the Front End Process - Management of the Early Phases in Product 
Development Projects. International Journal of Project Management, v. 20, p. 331-340, 2002. http://dx.doi. org/10.1016/S0263-7863(01)00030-8

OLIVEIRA, R. D. Design Industrial e Empresas de Pequeno Porte: Interações, Benefícios e Estratégias. 2000. Dissertação (Engenharia de Produção)-Universidade Federal de Minas Gerais, Belo Horizonte, 2000.

OTTOSSON, S. Dynamic Product Development - DPD. Technovation, v. 24, p. 207-217, 2004. http://dx.doi. org/10.1016/S0166-4972(02)00077-9

PINSONNEAULT, A.; KRAEMER, K. L. Survey research methodology in management information systems: an assessment. Journal of Management Information Systems, v. 10, n. 2, p.75-105, 1993.

ROMEIRO FILHO, E. A Implantação de Sistemas CAD na Indústria: Aspectos Gerenciais, Ergonômicos e Organizacionais. 1993. Dissertação (Engenharia de Produção)-Universidade Federal do Rio de Janeiro, Rio de Janeiro, 1993.

ROMEIRO FILHO, E. CAD na Indústria: Implantação e Gerenciamento. Rio de Janeiro: Editora da UFRJ, 1997.

ROMEIRO FILHO, E.; CRUZ, D. B. M. Estudo sobre a Gerência de Informações de Projeto em Grupo de Estudos de Engenharia Mecânica. In: ENCONTRO NACIONAL DE ENGENHARIA DE PRODUÇÃO - ENEGEP, 23., 2003, Florianópolis, Brazil. Anais... Ouro Preto: ABEPRO/ UFOP, 2003.

ROMEIRO FILHO, E. et al. O Uso das Ferramentas de CAD/CAE/CAM no Desenvolvimento de Produtos: o "Estado das Práticas" em Pequenas e Médias Empresas.
In: CONGRESSO BRASILEIRO DE ENGENHARIA DE FABRICAÇÃO - COBEF, 2., 2003, Uberlândia. Anais... Uberlândia: Associação Brasileira de Engenharia e Ciências Mecânicas, 2003.

ROMEIRO FILHO, E. et al. Design de produto. Rio de Janeiro: Elsevier, 2009.

RoOZEMburG, N. F. M.; EEKELS, J. Product Design: Fundamentals and Methods. Manchester: John Wiley \& Sons, 1995.

SEBRAE. Unidade de Estratégias e Diretrizes - UED. Estatísticas sobre MPE / Estatísticas das empresas formais. 2004. Disponível em: <www.sebrae.com.br/br/ ued/index.htm>. Acesso em: 10 maio 2010.

THOMKE, S.; FUJIMOTO, T. The Effect of "Front-Loading" Problem-Solving on Product Development Performance. Journal of Product Innovation Management, v. 17, p. 128-142, 2000. http://dx.doi.org/10.1016/S07376782(99)00031-4

VIEIRA, I. C. Competitividade Através da Gestão de Design: um Estudo dos Fatores Críticos de Sucesso no Processo de Desenvolvimento de Produtos em Empresas do Setor Medico-Odonto-Hospitalar e Laboratorial. 2002. Dissertação (Mestrado em Engenharia de Produção)Universidade Federal de Minas Gerais, Belo Horizonte, 2002.

YIN, R. K. Case Study Research: Design and Methods (Applied Social Research Methods). 4th ed. London: Sage Publications Inc, 2008. 